\title{
Living on polluted habitat: A preliminary study of marine debris impact to foraging waterbirds in Muara Angke Mangrove Ecosystem, Jakarta
}

\author{
Bhisma Gusti Anugra ${ }^{123^{*}}$, Nurul L. Winarni ${ }^{12}$, Dimas Haryo Pradana ${ }^{1}$, Selsa Artika Ayujawi ${ }^{1}$, Yulia Wulandari $^{2}$, Dalily \\ Syahruddin $^{2}$, and Yasman ${ }^{1}$ \\ ${ }^{1}$ Departement of Biology, Faculty of Mathematics and Natural Sciences, Universitas Indonesia, Depok, Indonesia \\ ${ }^{2}$ Research Center for Climate Change, Universitas Indonesia, Depok, Indonesia \\ ${ }^{3}$ Secretariat of the National Coordination Team for Marine Debris Handling, Jakarta, Indonesia
}

\begin{abstract}
Mangrove ecosystems are vulnerable to pollution such as marine debris. The presence of marine debris can affect the waterbird community. The present study aims to determine and analyze the effect of marine debris on waterbirds in the Muara Angke Mangrove Area. The research was undertaken from October to November 2020 at three research areas: Angke-Kapuk Protection Forest, Angke-Kapuk Nature Tourism Park, and Muara Angke Arboretum. Observations of waterbirds were carried out using the point count method and observations of marine debris density were conducted with the shoreline survey method developed by NOAA. To find out the pattern of marine debris distribution and its effect on waterbirds, we implemented Principal Component Analysis (PCA) and Spearman Correlation. In total, there were 13 species of waterbirds from 7 different orders in the three research areas. PCA analysis showed 6 variables in PC1 namely herbivorous duck, tactical surface, visual surface, habitat generalist, moderate specialist, and large. Further, PC2 produces 6 variables, namely pursuit diving, stalking, habitat generalist, aquatic generalist, and large. The results of the Spearman correlation indicated that three bird species were significantly negatively correlated with trash, those species are Anhinga melanogaster, Egretta garzetta, and Mycteria cinerea.
\end{abstract}

\section{Introduction}

Due to the expanding human population from the early twentieth century, marine trash has become a problem and a global concern since 1965 to 1970. $[1,2,3]$. The presence of marine debris negatively impacts on fishes, marine mammals, birds, and reptiles [4]. Entanglement was frequently documented in these creatures, with seabirds being the most vulnerable and also the most likely to swallow marine debris [5].

Research conducted by [6] on the coast of Brazil showed that $40 \%$ of birds have ingested marine debris, with mostly plastics. Another study conducted by [7] on the Korean coast reported that $93 \%$ of seabirds were entangled and accidentally ingested marine debris. Marine debris can also facilitate the spread of invasive species, that are accidentally carried by packagings, ropes or nets, fishing rods, and microplastics [8]. In addition, plastic materials in the marine debris causes pollution and toxic to organism. Their existence has continuously been accumulated in the environment as they are indecomposable $[9,10]$.

Indonesia ranks second in contributing marine debris in the world after China $[2,11]$. Indonesia produces 3.22 million tons of trash each year, and by 2025 , it is expected to create 150,000 tons of waste per day
$[12,13]$. This is due to urbanization which results in an increase in population as well as the consequences of improper waste management $[14,15]$.

The Muara Angke mangrove area is located in the Jakarta Bay which constitutes one of the most important habitats for waterbirds $[16,17]$. The area is, however, heavily polluted by domestic, industrial, and agricultural waste, as well as garbage carried in by rivers [18]. At least 8.32 tons of rubbish each day wind up in Jakarta's coastal areas, with 59 percent of it being plastic $[19,20]$. The disruption on waterbird community caused by marine debris in mangrove area is inevitable.

Waterbird is a group of birds that ecologically depends on wetlands, waterways, or shoreline $[21,22,23]$. Waterbirds forage in water to hunt for fishes, gastropods, crustaceans, molluscs, and aquatic invertebrates $[24,25,26]$. The variation of diet, prey distribution, and niche makes spesific waterbirds adapted various feeding technique $[27,28]$. For example, species like albatrosses feed on cephalopod hunt with surface-seizing technique $[29,30]$. Other species like sandpiper is either a tactile or visual surface feeder that hunt by probing its beak to search invertebrates [27,31].

Despite the fact that garbage poses a threat to birds, the studies regarding the impact of marine debris with waterbird communities in coastal areas are still very

\footnotetext{
* Corresponding author: bhismagius@gmail.com
} 
rarely addressed. Waterbirds are bioindicator of habitat quality, they can be a marker of either polluted area or high biodiversity $[32,33,34]$. We argue that waste may have impact on specific foraging patterns of waterbirds. The aim of this study is to determine and analyze the effect of waste on waterbirds community based on hunting techniques in the Muara Angke Mangrove Area.

\section{Method}

\subsection{Study area}

Field data collection was carried out in Angke Mangrove Area, Jakarta, Indonesia consisting of: Angke-Kapuk Protection Forest (AKPF), Angke-Kapuk Mangrove Nature Tourism Park (AKMNTP), and Muara Angke Arboretum with the total size of survey area is 155.09 ha (Figure 1).

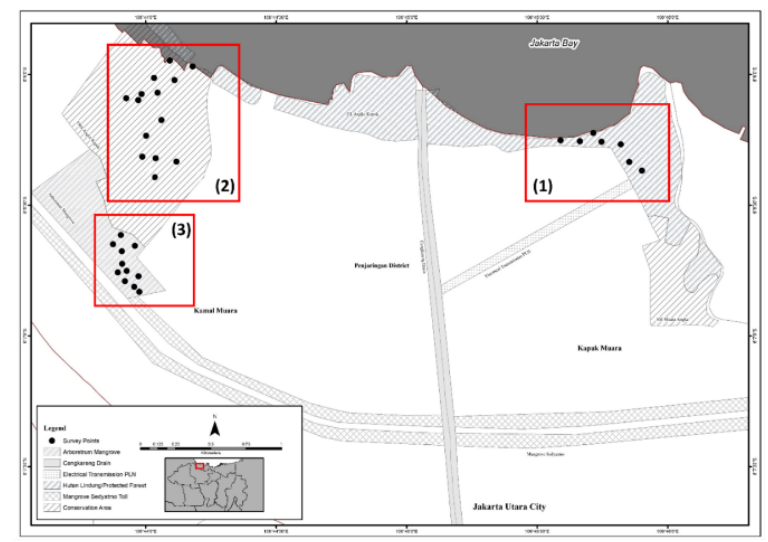

Figure. 1. Location of Muara Angke Mangrove Area, Jakarta,Indonesia: (1) Angke-Kapuk Protection Forest (AKPF), (2) Angke-Kapuk Mangrove Nature Tourism Park (AKMNTP), and (3) Muara Angke Arboretum

\subsection{Waterbird data collection}

The point count method [35] was applied to observe waterbirds. In total there were 32 observation points from three observation locations consisting of 7 points in Angke-Kapuk Protection Forest, 14 points in Angke-Kapuk Mangrove Nature Tourism Park, and 11 points in the Angke Arboretum with distance between each observation points in one location was approximately $100-150 \mathrm{~m}$. Observations were made during October 2020 - November 2020 in the morning (08:00 - 11:00) in western Indonesia Time (WIB). Each location was observed for 8 days. Observers conducted bird observations for 15 minutes in each point by recording the species name, number of individuals, distance to observer, feeding technique, size, and habitat utilization. Bird sizes were categorized into three groups, namely small $(<15 \mathrm{~cm})$, medium $(15-30 \mathrm{~cm})$, and large $(>30 \mathrm{~cm})$ [36]. The categorization of the waterbirds feeding technique refers to Bildsøe et al. [37], Ntiamoa-Baidu et al. [27], Kalam \& Urfi [38], Ryan [39], and Naher and Sarker [40]; namely pursuit diving, stalking, herbivorous duck, visual surface feeder, tactile surface feeder, and perch plunge. Bird identification and feed guild determination were carried out using the bird as well as scientific publication journals. Categorization of habitat utilization was divided into four groups referring to the IWCI (Index of Waterbird Community Integrity) [41], namely generalist, aquatic generalist, moderate specialist, and specialist.

\subsection{Habitat data collection}

Habitat data collection were carried out using point quarter method on the observation point with a diameter of $20 \mathrm{~m}$. The habitat data that recorded were canopy cover and the type of macrodebris. Canopy cover was measured using Canopeo apps by taking a picture of the tree coverage using smartphone perpendicular to the sky in the four different cardinal direction to get the average value of the canopy. The type of trash data recorded was only macrodebris. We recorded type of macrodebris data by using shoreline survey method developed by NOAA (National Oceanic and Atmospheric Administration) [42].The macrodebris data recorded were the amount, type, and size of the debris. The minimum size of macrodebris that recorded was $2.5 \mathrm{~cm}$, with two categorized consist of small (2.5$30 \mathrm{~cm})$ or large $(>30 \mathrm{~cm})$.

\subsection{Colour illustrations}

Macrodebris concentration was calculated using the formula referred to from Lippiat et al. [42].

$$
\begin{aligned}
& \text { Concentration of } \\
& \text { Macrodebris (items } \left./ \mathrm{m}^{2}\right)
\end{aligned}=\frac{\text { Number of macrodebris items observed }}{\text { Total area of observation }\left(\mathrm{m}^{2}\right)}
$$

Analysis of the relationship between waterbirds and marine debris was carried out using principal component analysis (PCA) [43]. The variables used in the PCA analysis are the presence of macrodebris types, feeding technique, habitat utilization (aquatic generalist, habitat generalist, and moderate specialist), and size. There are four categories for the presence of marine debris type in PCA: 1) organic only, 2) inorganic only, 3 ) both present, and 4) both absences. We also employed the Spearman rank correlation test to find out more about the correlation between waterbirds and marine debris by using the SPSS application.

\section{Results and discussion}

\subsection{Waterbird community}

Based on the observation, we identified 13 species of waterbirds from seven orders and eight families in the three study areas. Thirteen species of waterbirds were recorded using six different feeding strategies, with stalking being the most common. Based on habitat utilization category, most of the observed birds were in the aquatic generalist category (Table 1). We recorded 
the presence of Near-threatened species such as Anas gibberifrons in the Angke Kapuk Protected Forest and Anhinga menalogaster in the Angke-Kapuk Mangrove Nature Tourism Park, as well as the Endangered Mycteria cinerea in the Angke-Kapuk Mangrove Nature Tourism Park, therefore Muara Angke mangrove area served as an important habitat for the survival of this Near-threatened species.

Table 1. Waterbird's species with their feeding technique and habitat utilization.
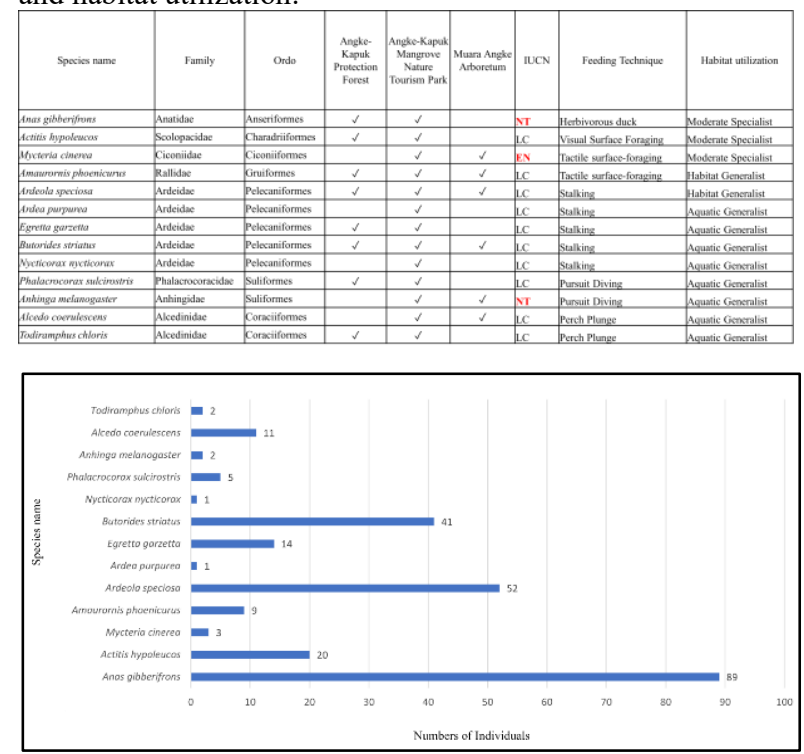

Fig. 2. Total number of waterbirds individuals in AngkeKapuk Protection Forest, Angke-Kapuk Mangrove Nature Tourism Park, and Muara Angke Arboretum

The low density of mangroves in the Muara Angke Arboretum is thought to affect the number of waterbirds species in that area. According to the observations, both the presence of waste and the presence of waterbirds tended to occur at points where the canopy cover was higher. The results of canopy cover measurement also show that Muara Angke Arboretum had the lowest canopy percentage (figure 3 ). Only six species were found in the Arboretum, compared to eight species in the AKPF and thirteen in the AKMNTP. Waterbird diversity will be increased in the area due to the high density and diversity of mangroves [44]. This is due to the diverse array of arthropods, mollusks, and fish that provide food for waterbirds in mangrove habitats $[45,46]$. In addition, the canopy of mangroves serves as a resting and breeding area for a variety of waterbird species $[47,48]$.

It's worth noting that out of the 32 observation spots, we discovered three species that presented frequently when there was no marine debris. Those species were Anhinga melanogaster, Mycteria cinerea, and Nycticorax nycticorax which are sensitive to habitat disturbances and prefer to live in locations with little or no marine debris $[49,50]$. More observations, however, are required to corroborate this phenomena.

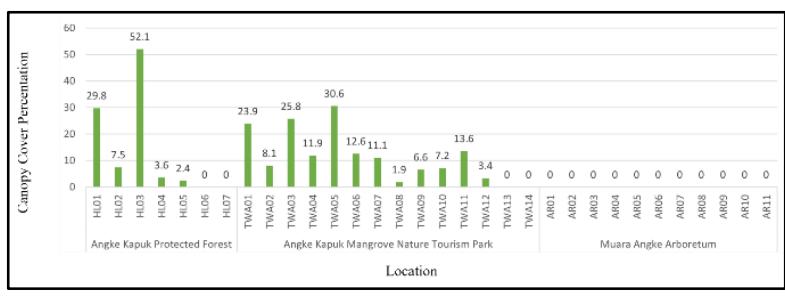

Fig. 3. Canopy cover percentage from all observation points in Angke-Kapuk Protection Forest, Angke-Kapuk Mangrove Nature Tourism Park, and Muara Angke Arboretum

\subsection{R Marine debris details}

Plastic was the most dominating type of waste $(89 \%)$ in all study sites, followed by processed wood $(7 \%)$, and rubber $(2 \%)$. Meanwhile, the other type of waste such as metal, cloth, glass, and organic waste is less than $2 \%$ (Figure 4). Of all types of plastic, waste in the form of fragments is the most common type of plastic waste (1287 items), followed by cups (976 items), and food wrappers (876) (Table 2). AngkeKapuk Protection Forest (AKPF) is the location with the most total waste (2701 items), followed by AngkeKapuk Mangrove Nature Tourism Park (AKMNTP) (1593 items). Interestingly, there is no record of waste in Muara Angke Arboretum (Table 3). The absence of marine debris in Muara Angke Arboretum is possibly due to having more open-space area. Further, the presence of mangroves is less dense than in AKPF and AKMNTP. Mangroves serve as a pollutant filter. Meanwhile, mangroves are likely to have become pollutant accumulation regions because the waste that passes through their roots is strained, resulting in a lot of trash in the mangrove area $[51,52]$.

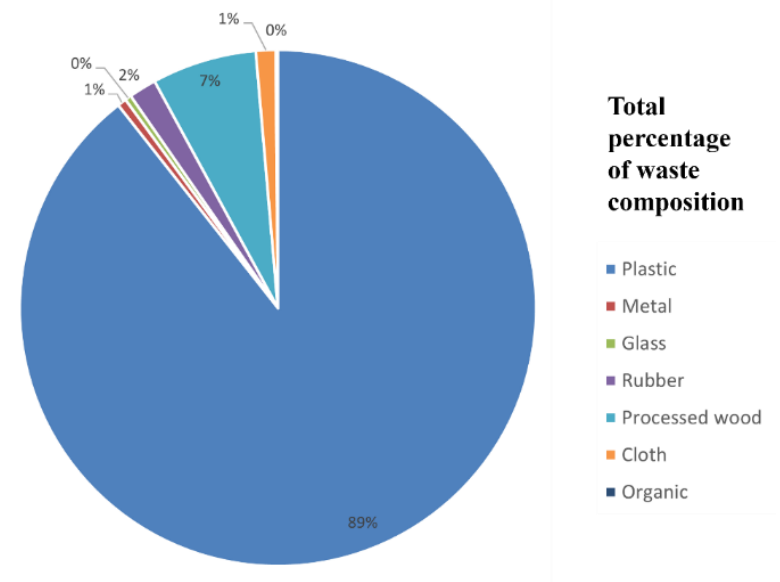

Fig. 4. Total percentage of waste composition from AngkeKapuk Protection Forest, Angke-Kapuk Mangrove Nature Tourism Park, and Muara Angke Arboretum.

Table 2. The amount the types of plastic with the total amount of each inorganic macrodebris from Angke-Kapuk Protection Forest, Angke-Kapuk Mangrove Nature Tourism Park, and Muara Angke Arboretum. 


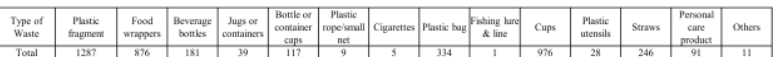

Table 3. Comparison of amount of macrodebris in each location.

\begin{tabular}{|c|c|c|c|c|c|c|c|c|}
\hline & & & & & Int of $W_{\text {aste }}$ & & & \\
\hline Location & Plastic & Metal & Ghass & Rubber & 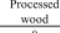 & Cloth & Organic & TOTAL \\
\hline 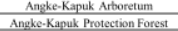 & $\frac{0}{2701}$ & $\frac{0}{20}$ & $\frac{0}{14}$ & $\frac{0}{61}$ & $\frac{0}{182}$ & 0 & $\frac{0}{6}$ & $\frac{0}{3041}$ \\
\hline 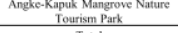 & 1593 & 7 & 3 & tot & 133 & 3 & 0 & 1,63 \\
\hline
\end{tabular}

\subsection{Waterbirds and macrodebris connection}

Based on PCA results, there were two main components with eigenvalue $>2$. We used varimax rotation on the principal components to interpret data easier [53]. The PC 1 and PC 2 are then interpreted through a scatter plot with PC 1 on the $\mathrm{X}$ axis and PC 2 on the $\mathrm{Y}$ axis (Figure 5). The results of the rotated component obtained, suggested that PC 1 composed of herbivorous duck (0.796), tactical surface (0.416), visual surface (0.691), generalist habitat (0.591), moderate specialist (0.940), and large (0.670). Meanwhile, PC 2 included pursuit diving (0.547), stalking (0.829), habitat generalist (0.506), aquatic generalist (0.799), and large (0.735).

The scatter plot findings typically suggest that the lack of waste variable and the presence of inorganic waste variable are overlap, although the distribution of inorganic waste variables appears to be more clustered, whilst the absence waste variable distribution tends to be wider. This suggested that the absence of waste and presence of inorganic waste tended to favour birds with pursuit diving (Phalacrocorax sulcirostris and Anhinga melanogaster), stalking (species from Ardeidae Family), herbivorous duck (Anas gibberifrons), tactical surface feeder (Mycteria cinerea and Amaurornis phoenicurus), and visual surface feeder (Actitis hypoleucos). In addition, large-sized waterbirds with habitat utilization habitat generalist, aquatic generalist, and moderate specialist are also influenced by waste.

A Spearman rank correlation test was also employed to examine the association between waterbirds and marine trash. The findings revealed that the presence of inorganic waste was adversely connected with the presence of ten species of waterbirds, with three species being strongly correlated with inorganic waste. Anhinga melanogaster, Egretta garzetta, and Mycteria cinerea are the three species (Table 4). In terms of size, the three species are large species $(>30 \mathrm{~cm})$ but have different feeding techniques. Anhinga melanogaster is a species that hunts by pursuit diving and belongs to the aquatic generalist group [54,39]. Egretta garzetta hunts by stalking technique and belongs to the aquatic generalist group such as Anhinga melanogaster [55,36]. Meanwhile, Mycteria cinerea belongs to the moderate specialized group and is a tactile surface hunter that pursues its prey by probing its beak in water. $[38,36]$.

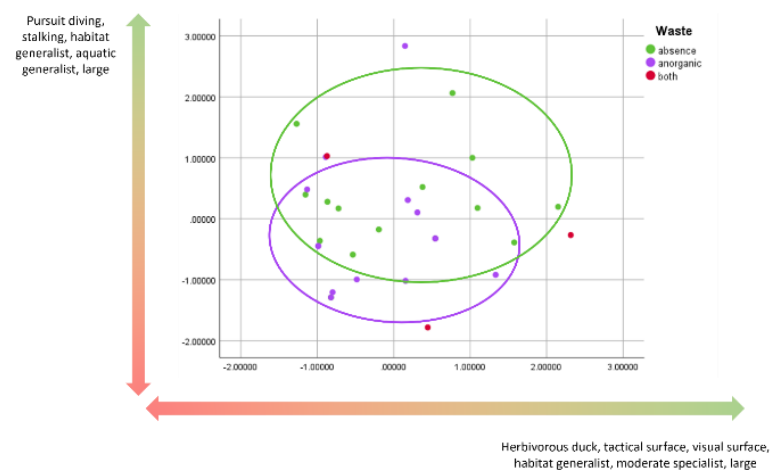

Fig. 5. Scatter plot figure of the categories for the presence of waste type based on the results of PCA

Table 4. Results of the Spearman correlation test between the relative abundance of each bird species and concentrations of inorganic and organic wastes

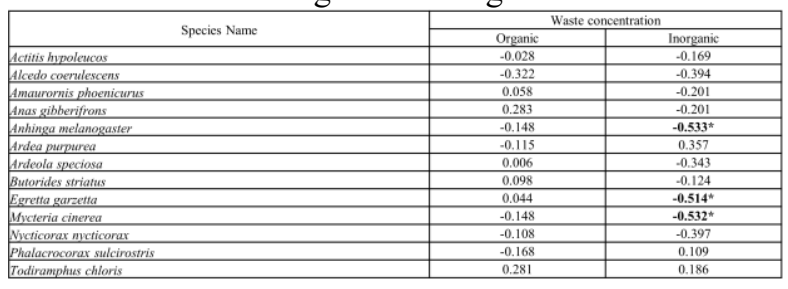

Note: *Correlation is significant at the 0.05 level

Based on the observation, inorganic waste was found in almost all observation locations except Muara Angke Arboretum. Bird species belong to specialist groups such as Mycteria cinerea were rarely found in habitats polluted by inorganic waste $[56,36]$. This is in line with the results of observations, where Anhinga melanogaster and Mycteria cinerea were recorded at observation points with the absence of waste. In general, inorganic waste can reduce bird abundance [5]. This occurred because inorganic waste can change the water flow system and create sedimentation. Therefore, it has an impact on the loss of food sources for birds such as crustaceans and fish [41,57]. In addition, the accumulation of chemical compounds from inorganic waste depositing in waters may poison and cause mortality of organisms thus trigger disruption in the food chain $[58,7,59]$.

The threat of waste to waterbirds can also be influenced by the feeding techniques used by the birds [60]. Research conducted by [61] documented that birds with pursuit diving hunting techniques such as Anhinga melanogaster and Phalacrocorax sulcirostris tend to swallow more waste. Several other hunting techniques that have a higher risk of ingesting waste are surface seizing, diving, and filter feeding [62,63]. Although some species like Egretta garzetta and Mycteria cinerea have good vision when hunting, there are still many records of waterbirds accidentally ingesting waste due to the shape and color of the waste that is similar to their food $[60,63,64]$. Research conducted by [65] showed that some species of waterbirds accidentally ingest litter since the shape of the litter is similar to that of cuttlefish. In addition, waste that is accidentally ingested by waterbirds is generally light or white in color $[66,67]$. Hence, the better management of the area should be 
improved to avoid such problems. Based on Spearman rank correlation test, some species were positively correlated with the presence of organic waste.

From our observations, species like Actitis hypoleucos, Amaurornis phoenicurus, and Anas gibberifrons were found hunting at points where the waste was present, it is suspected that these species forage inorganic waste (Figure 6). In contrast to inorganic waste, some bird species may still be able to forage in habitats with organic waste [36] since it provides a food source for birds like maggots, flies, and grasshoppers and also household waste like fish meat, chicken, eggs, seeds, and fruit [5,68]. Furthermore, the presence of waste landfills can increase the abundance and survival rates of some bird species in local scale [69].

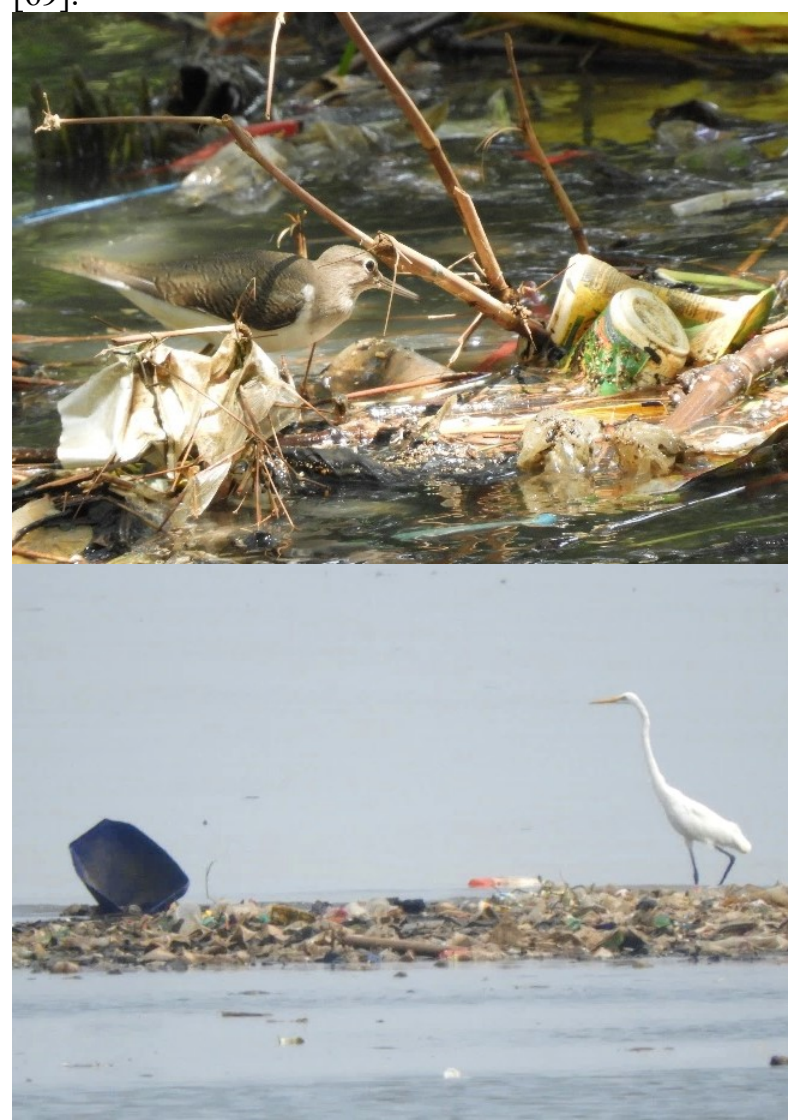

Fig. 6. Some species that foraging in waste coverage: Actitis hypoleucos in Angke Kapuk Protected Forest (left), and Ardea alba outside Angke Kapuk Protected Forest (right)

\subsection{The impact of marine debris to mangrove and future action}

According to the observations, AKPF has the highest waste record, followed by AKMNTP. The mangrove area of Muara Angke was close to a residential neighborhood in Jakarta, which was bustling with human activity. The Muara Angke mangrove, which is located in the Jakarta estuary, was made more vulnerable to contamination by domestic, industrial, and agricultural waste due to the high level of human activity $[18,70]$. A research [71] reported that plastic and styrofoam dominated garbage in the Muara Angke mangrove area. As a result of this fact, the Muara Angke mangrove region has been classified as severely damaged [72].

One of the most serious dangers to the mangrove ecosystem was inorganic waste. Inorganic waste cover can disrupt the flow of nutrients which are used as nutrients for mangroves [73,72]. Furthermore, a large pile of garbage in mangrove roots reduces oxygen delivery resulting in mangrove mortality $[74,75,76]$. Heavy metals such as $\mathrm{Pb}, \mathrm{Cr}$, and $\mathrm{Cg}$ can be released by marine debris that settles in the water. They may affect the salinity of the water and endangering the food chain $[71,75]$.

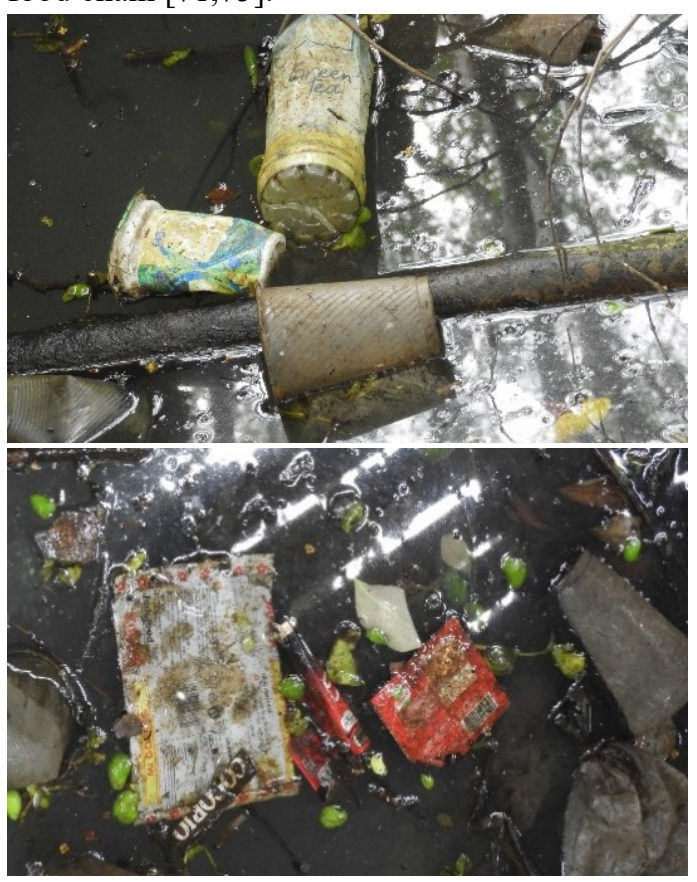

Fig. 7. Plastic waste in Muara Angke mangrove area : plastic bottle \& cups (above), and food wrappers (below).

Indonesia, being the world's second-largest producer of marine waste, faces a major marine debris problem [2]. Every year Indonesia produces 3.22 million tons of waste that is not managed properly, and it is estimated that by 2025 Indonesia will produce 150,000 tons of waste per day [12,13]. Various efforts have been made to prevent the entry of waste in coastal areas, one of which is through the enactment of Law Number 18 of 2008 concerning Waste Management, and Government Regulation Number 81 of 2012 concerning Management of Household Waste and Waste Similar to Household Waste. Furthermore, the Indonesian government is committed to reducing the production of waste by $30 \%$ and plastic waste by $70 \%$ by 2025 through various efforts such as the creation of the National Action Plan for Marine Waste Management (RAN PSL), the application of 3R (Reduce, Reuse, Recycle), land-based derived plastic waste, and the application of a circular economy [77,19].

Another possible effort to protect coastal areas is to rehabilitate mangrove ecosystems. The mangrove rehabilitation can be done by planting native mangrove vegetation Avicennia marina, Rhizophora mucronata, 
Rhizophora stylosa, Sonneratia caseolaris, and Excoecaria agallocha that commonly found in Muara Angke mangrove area [73,78]. Based on research conducted by [79], some species like Rhizopora mucronate and Avicennia alba are highly tolerant against marine debris and heavy metals. Furthermore, long term management and mitigation are important to maintain mangrove ecosystem [80,79].

Through environmental education and counseling, the community can also contribute towards the management of marine waste in mangrove areas $[73,75]$. Moreover, the community may also participate in some joint activities with various stakeholders [81 Furthermore, by understanding the ecosystem services given by mangroves, the community can become more environmentally conscious, particularly those who reside in coastal areas $[73,81,82]$.

\section{Conclusions}

Muara Angke mangrove area is a habitat for various species of water birds. Our research recorded 13 species of waterbirds from seven different orders and eight families. Plastic waste is the most dominant waste $(89 \%)$, followed by processed wood $(7 \%)$, and rubber $(2 \%)$ waste. A total of 10 species of waterbirds were negatively correlated with the presence of inorganic waste, with three species were significantly negatively correlated with inorganic waste. The presence of inorganic waste in the Muara Angke mangrove threatens the existence of birds and the mangrove ecosystem. As an important area for various waterbird's conservation, it is necessary to affectively plan and carry out rehabilitation and waste management effectively and considerably.

\section{Acknowledgements}

This study was carried out through the funding from Universitas Indonesia Hibah PUTI Q2 (NKB1659/UN2.RST/HKP.05.00/2020). Thank you for all the staff of the Research Center for Climate ChangeUniversitas Indonesia who supports and help us during research and analysis. We also would like to thank you for Angke-Kapuk Protected Forest, Angke-Kapuk Nature Tourism Park, and Angke Kapuk Arboretum management. We followed all applicable ethical guidelines and permit to conduct research following regulations in Indonesia. This research was conducted during Covid-19 pandemic, all observers followed health protocols in accordance with applicable regulations.

\section{References}

1. UNESCAP. 2014. What is good governance. United Nations-Economic and Social Commision for Asia and the Pacific, Bangkok.

2. Jambeck, J.R., Geyer, R., Wilcox, C., Siegler, T.R., Perryman, M., Andrady, A, Narayan, R., Law, K.L.
2015. Plastic waste inputs from land into the ocean. Science, 347(6223), 768-771.

3. Ryan, P.G. 2015. A brief history of marine litter search. In Bergmann, M., Gutow L, Klages, M. (eds.). 2015. Marine anthropogenic litter. Springer, 468 pages.

4. Secretariat of CBD and STAP-GEF. 2012. CBD technical series No.67 - Impacts of marine debris on biodiversity: Current status and potential solutions. Secretariat of the Convention on Biological Diversity, Montreal, 61 pages.

5. Plaza, P.I., Lambertucci, S.A. 2017. How are garbage dumps impacting vertebrate demography, heath, and conservation?. Global Ecology and Conservation, 12, 9-20.

6. Tourinho, P.S., do Sul, J.A.I., Fillmann, G. 2010. Is marine debris ingestion still a problem for the coastal marine biota of southern Brazil?. Marine Pollution Bulletin, 60(3), 396-401.

7. Hong, S., Lee, J., Jang, Y.C., Kim, Y.J., Kim, H.J., Han, D., Hong, S.H., Kang, D., Shim, W.J. 2012. Impacts of marine debris on wild animals in the coastal area of Korea. Marine Pollution Bulletin, 18.

8. Gall, S.C. and Thompson, R.C. 2015. The impact of debris on marine life. Marine Pollution Bulletin, 110.

9. Irianto, I.K. 2018. Threat of trash to environment al tourism in area mangrove forest. Tourism and Evens International Seminar, TEIS Committee, 240-246.

10. Napper, I. E., Thompson, R.C. 2020. Plastic debris in the marine environment: History and future challenges. Global Challenges, 4, 1-9.

11. Lebreton, L.C., Van Der Zwet, J., Damsteeg, J.W., Slat, B., Andrady, A., Reisser, J. 2017. River plastic emissions to the world's oceans. Nature communications, 8(1), 1-10.

12. World Bank. 2012. What a waste: A global review of solid waste management. Urban Development \& Local Government Unit, World Bank, Washington, xiii +98 pages.

13. World Bank. 2018. Hotspot sampah laut di Indonesia: Kajian Cepat laporan sintesis. World Bank.

14. Ngoc, U. N., Schnitzer, H. 2009. Sustainable solutions for solid waste management in Southeast Asian countries. Waste management, 29(6), 19821995.

15. Lebreton, L., Andrady, A. 2019. Future scenarios of global plastic waste generation and disposal. Palgrave Communications, 5(1), 1-11.

16. FORCLIME. 2014. Urban Forest: Ruang Terbuka Hijau dan Keanekaragaman Hayati Jakarta. GIZ FORCLIME, Jakarta, 54 pages.

17. Birdlife International. 2021. Country profile: Indonesia. http://datazone.birdlife.org/ 
18. Cordova, M.R. 2017. Pencemaran plastik di laut. Oseana, XLII(3), 21-30.

19. Cordova, M.R., Nurhati, I.S. 2019. Major sources and monthly variations in the release of landderived marine debris from the greater Jakarta area, Indonesia. Scientific Reports, 9, 18730.

20. WALHI Jakarta. 2020. Tinjauan lingkungan hidup Jakarta 2020. WALHI Eksekutif Nasional

21. Elfidasari, D., Junardi. 2006. Keragaman burung air di kawasan hutan mangrove Peniti, Kabupaten Pontianak. Biodiversitas, 7(1), 63-66.

22. Lee, W.S., Choi, C.Y., Kim, H. 2018. Field Guide to the Waterbirds of Asean. ASEAN-Korea Environmental Cooperation Unit (AKECU), Seoul, 299 pages.

23. Clemens, R., Driessen, J., Ehmke, G. 2019. Australian Bird Index Phase 2 - Developing Waterbird Indices for National Reporting. Unpublished report for the Department of the Environment. BirdLife Australia, Melbourne.

24. Karmiris, I.L.I.A.S., Kazantzidis, S.A.V.A.S., Papachristou, T.G. 2010. Variation in diet composition of wintering waterfowl among Greek wetlands. Avocetta, 34(1), 21-28.

25. Siregar, N.H., Jumilawaty, E. 2018. Diversitas dan potensi pakan burung pantai di kawasan Pantai Baru, Kabupaten Deli Serdang Sumatera Utara. Journal of Science and Applicative Technology Institut Teknologi Sumatera, 2(2), 8-15.

26. Antón-Tello, M., Britto, V. O., Gil-Delgado, J. A., Rico, E., Dies, J. I., Monrós, J. S., Vera, P. 2021. Unravelling diet composition and niche segregation of colonial waterbirds in a Mediterranean wetland using stable isotopes. Ibis, 163(3), 913-927.

27. Ntiamoa-Baidu, Y.A.A., Piersma, T., Wiersma, P., Poot, M., Battley, P.H.I.L., Gordon, C., 1998. Water depth selection, daily feeding routines and diets of waterbirds in coastal lagoons in Ghana. Ibis, 140(1), 89-103.

28. Petalas, C., Lazarus, T., Lavoie, R.A., Elliott, K.H., Guigueno, M.F. 2021. Foraging niche partitioning in sympatric seabird populations. Scientific reports, 11(1), 1-12.

29. Novcic, I., Beauchamp, G. 2018. Forager density effect on feeding rates in spring staging semipalmated sandpipers using different foraging modes. Canadian Journal of Zoology, 1-27.

30. Sumartono, N.I.R., Hernowo, J.B., Santoso, N. 2019. Komunitas dan guild burung pantai di kawasan Pantai Trisik, Yogyakarta. Media Konservasi, 24(3), 287-292.

31. Kelm, M., Arbor, D. 2021. Shorebird behavior at two sites on San Juan Island. Student Research Paper, University of Washington, pp. 1-15. https://digital.lib.washington.edu/researchworks/ha ndle/1773/ 47173.

32. Amat, J.A., Green A.J. 2010. Waterbirds as bioindicators of environmental conditions. In Hufford, C., Schneider, M., Cowx, I.G. 2010.
Conservation monitoring in freshwaters habitats. Springer, Netherlands, 45-52.

33. Uribe-Hernández, R., Amezcua-Allieri M.A., De Oca-García M.A.M, JuárezMéndez C., Eguia-Lis J.A.Z., Izquierdo M.S., Tenorio-Torres M.A. 2012. Ecological indices for birds and their relationship with the environmental quality of a wetland impacted by waste oil. Interciencia, 37(10), 762768.

34. Egwumah, F.A., Egwumah, P.O., Edet, D.I. 2017. pParamount roles of wild birds as bioindicators of contamination. International Journal of Avian \& Wildlife Biology, 2(6), 1-7.

35. Bibby, C., Jones, M., Marsden, S. 1998. Expedition field techniques: bird surveys. Royal Geoghrapical Society, London, pp 134.

36. Ayujawi, S.A., Winarni, N.L., Pradana, D.H. 2021. Short communication: Bird correlations with waste in Muara Gembong, West Java, Indonesia. Biodiversitas, 22(9), 3872-3879.

37. Bildsøe, M., Jensen, I.B., Vestergaard, K.S. 1998. Foraging behaviour of cormorants Phalacrocorax carbo in pound nets in Denmark: the use of barrel nets to reduce predation. Wildlife biology, 4(2), 129-136.

38. Kalam, A., Urfi, A.J. 2007. Foraging behaviour and prey size of the painted stork. Journal of Zoology, 274, 198-204.

39. Ryan, P.G. 2007. Diving in shallow water: The foraging ecology of dartes (Aves: Anhingidae). Journal of Avian Biology, 38, 507-514.

40. Naher, H., Sarker, N.J. 2015. Prey capturing techniques of white-throated kingfisher (Halcyon smyrnensis) in Dhaka, Bangladesh. Jagannath University Journal of Life and Earth Sciences, 1(1), 95-102.

41. DeLuca, W.V., Studds, C.E., Rockwood, L.L., Marra, P.P. 2008. Influence of land use on the integrity of marsh bird community of Chesapeake Bay, USA. The Society of Wetland Scientists, 24(4), 837-847.

42. Lippiatt, S., Opfer, S., Arthur, C. 2013. Marine Debris Monitoring and Assessment. NOAA Technical Memorandum NOS-OR\&R-46, NOAA Marine Debris Division, United States.

43. Waite, S. 2000. Statistical Ecology in Practice: A Guide to Analysing Environmental and Ecological Field Data. Pearson education, London, 414 pages.

44. Mohd-Azlan, J., Noske, R.A., Lawes, M.J. 2015. The Role of Habitat Heterogeneity in Structuring Mangrove Bird Assemblages. Diversity, 7, 118136.

45. Field, C.B., Osborn, J.G., Hoffman, L.L., Polsenberg, J.F., Ackerly, D.D., Berry, J.A., Bjorkman, O., Held, A. Matson, P.A., Mooney, H.A. 1998. Mangrove biodiversity and ecosystem function. Global Ecology and Biogeography Letters, 7, 3-14. 
46. Rajpar, M.N., Zakaria, M. 2013. Mangrove fauna of Asia. In Faridah-Hanum, I., Latiff, A., Hakeem, K.R., Ozturk, M. (eds.). 2014. Mangrove ecosystem of Asia: Status, challenges and management strategies. Springer-Verlag, New York, xvi +473 pages.

47. Nagelkerken, I., Blaber, S.J.M., Bouillon, S., Green, P., Haywood, M., Kirton, L.G., Meynecke, J.O., Pawlik, J., Penrose, H.M., Sasekumar, A., Somerfield, P.J. 2008. The habitat function of mangroves for terrestrial and marine fauna: A review. Aquatic Botany, 89, 155-185.

48. Sandilyan, S., Kathiresan, K. 2012. Mangrove conservation: A global perspective. Biodiversity Conservation, 21, 3523-3542.

49. Aziz, A.A, Phinn, S., Dargusch, P. 2015. Investigating the decline of ecosystem services in a production mangrove forest using Landsat and Object-based Image Analysis. Estuarine Coastal and Shelf Science, 164, 353- 366.

50. Narayanan, Prasanth, S., Thomas, A.P. 2016. Feeding rate and diet of the near threatened oriental darter Anhinga melanogaster in Kuttanad Wetlands of Kerala, India, Journal of Global Biosciences, 5(1), pp. 3450-3460.

51. Mulyadi, E., Laksmono, R., Aprianti, D. 2009. Fungsi mangrove sebagai pengendali pencemar logam berat. Envirotek : Jurnal Ilmiah Teknik Lingkungan, 1 (Edisi Khusus), 33-39.

52. Viljoen, J.M.M., Schenck, C.J, Volschenk, L., Blaauw, P.F, Grobler, L. 2021. Household waste management practices and challenges in a Rural Remote Town in the Hantam Municipality in the Northern Cape, South Africa. Sustainability, 13, 5903.

53. Umar, H.B. 2009. Principal Component Analysis (PCA) dan Aplikasinya dengan SPSS. Jurnal Kesehatan Masyarakat, 3(2), 97-101.

54. Nelson, J.B. 2005. Pelicans, cormorants, and their relatives. Oxford University Press, Oxford, 702 pages.

55. Zackeisha, N. 2020. Penilaian dampak gangguan antropogenik terhadap ekosistem mangrove menggunakan index of waterbird community integrity di Taman Wisata Alam Angke Kapuk, Jakarta Utara. Undergraduate theses. Universitas Indonesia, Depok, pp xii+60, Unpublished.

56. Sica Y.V., Gavier-Pizarro G.I., Pidgeon, A.M., Travaini, A., Bustamante, J., Radeloff, V.C., Quintana, R.D. 2018. Changes in bird assemblages in a wetland ecosystem after 14 years of intensified cattle farming. Austral Ecol., 43, 786-797.

57. Sandilyan, S., Kathiresan, K. 2012. Plastic - a formidable threat to unique biodiversity of Pichavaram mangroves. Current Science, 103(11), 1262-1263.

58. Butterworth, A., Clegg, I., Bass, C. 2012. Untangled - Marine debris: A Global Picture of The Impact on Animal Welfare and of Animal-Focused
Solutions. World Society for the Protection of Animals, London, 75 pages

59. Hong, S.H., Shim, W.J., Han, G.M., Ha, S.Y., Jang, M., Rani, M., Hong, S., Yeo, G.Y. 2013. Levels and profiles of persistent organic pollutants in resident and migratory birds from an urbanized coastal region of South Korea. Science of the Total Environment, 1-8.

60. Derraik, J.G.B., 2002. The pollution of the marine environment by plastic debris: a review. Marine Pollution Bulletin, 44(9), 842-852.

61. Roman, L., Bell, E., Wilcox, C., Hardesty, B. D., Hindell, M. 2019. Ecological drivers of marine debris ingestion in Procellariiform seabirds. Scientific reports, 9(1), 1-8.

62. Tavares, D.C., de Moura, J.F., Merico, A., Siciliano, S. 2017. Incidence of marine debris in seabirds feeding at different water depths. Marine Pollution Bulletin, 119(2), 68-73.

63. Roman, L., Hardesty, B.D., Hindell, M.A., Wilcox, C. 2019. A quantitative analysis linking seabird mortality and marine debris ingestion. Scientific Reports, 9(1), 1-7.

64. Savoca, M.S., Wohlfeil, M.E., Ebeler, S.E., Nevitt, G.A. 2016. Marine plastic debris emits a keystone infochemical for olfactory foraging seabirds. Science advances, 2(11), e1600395

65. Cadée, G. C. 2002. Seabirds and floating plastic debris. Marine Pollution Bulletin, 44(11), 12941295.

66. Acampora, H., Schuyler, Q.A., Townsend, K.A., Hardesty, B.D. 2013. Comparing plastic ingestion in juvenile and adult stranded short-tailed shearwaters (Puffinus tenuirostris) in Eastern Australia. Marine Pollution Bulletin, 78(1-2), 6368.

67. Roman, L., Schuyler Q.A., Hardesty, B.D., Townsend, K.A. 2016. Anthropogenic debris ingestion by avifauna in Eastern Australia. PLoS ONE, 11(8), e0158343.

68. Fadila, M.I., Mardiastuti, A., Mulyani, Y.A. 2020. Pemanfaatan Tempat Pembuangan Akhir (TPA) Jatibarang Semarang oleh kuntul kerbau (Bubulcus ibis Linnaeus 1758). Master Theses, IPB University, Bogor, Indonesia, pp vi +32.

69. Marasinghe, S.S., Perera, P.K.P, Dayawansa, N.P. 2015. Composition and functional diversity of the avifaunal community at an urban landfill in Colombo District, Sri Lanka. Proceedings of the International Forestry and Environment Symposium 2015 of the Department of Forestry and Environmental Science, University of Sri Jayewardenepura, Sri Lanka.

70. Rositasari, R., Puspitasari R., Nurhati, I.S., Purbonegoro, T., Yogaswara, D. 2017. 5 dekade LIPI di Teluk Jakarta: Review penelitian oseanografi di Teluk Jakarta 1970-2015. Pusat Penelitian Oseanografi Lembaga Ilmu Pengetahuan Indonesia, Jakarta, ix +102 pages. 
71. Hastuti, A.R., Yulianda, F., Wardianto, Y. 2014. Distribusi spasial sampah laut di ekosistem mangrove Pantai Indah Kapuk, Jakarta. Bonorowo Wetlands, 4(2), 94-107.

72. Suryono, D.D. 2019. Sampah plastik di perairan pesisir dan laut: Implikasi kepada ekosistem pesisir DKI Jakarta. Jurnal Riset Jakarta, 12(1), 17-23.

73. Purwoko, P.F., Wulandari, A.A., Benariva, A.P., Tiara, A., Sabiel, M.Q.T., Risandi, R., Jannati, A., Nugraha, A., Noriko, N., Priambodo, T. 2015. Ketahanan vegetasi wilayah mangrove Suaka Margasatwa Muara Angke, DKI Jakarta terhadap sampah dari aliran sungai. Seminar Nasional PBI, 1-8.

74. Ivar do Sul, J.A., Costa, M.F., Silva-Cavalcanti, J.S., Araújo, M.C.B. 2014. Plastic debris retention and exportation by a mangrove forest patch. Marine Pollution Bulletin, 78(1-2), 252-257.

75. Sasongko, D.A., Kusmana, C., Ramadan, H. 2014. Strategi pengelolaan Hutan Lindung Angke Kapuk. Jurnal Pengelolaan Sumberdaya Alam dan Lingkungan, 4(1), 35-42.

76. Suyadi, Manullang C.Y. 2020. Distribution of plastic debris pollution and it is implications on mangrove vegetation. Marine Pollution Bulletin, $160,111642$.
77. McKinsey \& Company and Ocean Conservancy. 2015. Stemming the Tide: Land-Based Strategies for A Plastic-Free Ocean. McKinsey \& Company and Ocean Conservancy, Chicago, US.

78. Hilmi, E., Kusmana, C., Suhendang, E., Iskandar. 2017. Correlation analysis between seawater intrusion and mangrove greenbelt. Indonesian Journal of Forestry Research, 4(2), 151-168.

79. Priyono, A. 2010. Panduan praktis Teknik rehabilitasi mangrove di kawasan pesisir Indonesia. KeSEMaT, Semarang, xii +49.

80. Huda, N. 2008. Strategi kebijakan pengelolaan mangrove berkelanjutan di wilayah pesisir Kabupaten Tanjung Jabung Timur Jambi. Tesis Program Pascasarjana Univeristas Diponegoro, iv + 99.

81. Sofian, A., Kusmana, C., Fauzi, A. Rusdiana O. 2020. Evaluasi kondisi ekosistem mangrove Angke Kapuk Teluk jakarta dan konsekuensinya terhadap jasa ekosistem

82. Tetelepta, J.M.S., Loupatty, S.R., Wawo, M. 2020. Sustainable management strategy for mangrove forest of Pelita Jaya Bay and Kotania Bay, Western Seram, Indonesia. Jurnal Triton, 16(2), 53067. 